\title{
TUBERCULOUS RHEUMATISM
}

\author{
BY \\ JOAN M. BREMNER \\ University of Leeds and Regional Rheumatism Centre, Harrogate, Yorks
}

The problem of "tuberculous rheumatism" has been studied with a varying amount of interest during the past 60 years, mainly in France, though some work has been done in Great Britain and the United States. Layani, Durupt, and Chaouat (1956) reviewed the subject and tried to define the syndrome more exactly by using a test specific for tuberculosis, the tuberculin test. The results were compared with those of a similar injection of nonspecific foreign protein, in patients with tuberculosis associated with past or present articular lesions, and in others with rheumatoid arthritis. A similar attempt at definition, using a different approach, the Rose-Waaler (D.A.T.) test for rheumatoid arthritis, has been made in the three cases reported below.

\section{Case Reports}

*Case 1, a married woman, aged 49 years, had rheumatoid arthritis which started with pain in the neck and hands at the age of 32 years, followed by gradual involvement of most joints; after some years and following several falls, the left knee worsened considerably, though there was no constitutional upset or loss of weight.

On admission the patient complained chiefly of this joint, which was swollen and tender with very limited movement; most of the other joints were affected and there was ulnar deviation of the right hand.

Laboratory Findings.-Haemoglobin 63 per cent., white blood cells 4,500 c.mm., polymorphs 58 per cent., lymphocytes 39 per cent.

Blood sedimentation rate $43 \mathrm{~mm} . / 1 \mathrm{hr}$.

$X$ ray of the left knee showed osteoporosis and loss of joint space.

The Rose-Waaler test was positive $1: 256$ in 1957, i.e. at a late stage of the disease.

Progress.-Though the general condition and other joints improved with treatment, the left knee remained very painful. The patient was given two intra-articular injections of hydrocortisone with temporary slight relief, but when a third injection was attempted, some synovial fluid was aspirated and found to be turbid. Tubercle bacilli were found in the fluid both microscopically and on culture. No other form of tuberculosis was found, and arthrodesis of the knee was performed.

After this, the patient's condition improved considerably for about 2 years, but she then relapsed with

* This case was reported to a meeting of the Heberden Society at Harrogate in May, 1954. reactivation of arthritis in several joints and has recently died from an intercurrent pyelo-nephritis and bronchopneumonia.

Post-mortem Examination.-No other evidence of tuberculosis was found.

Case 2, a married woman aged 47 years, the sister of Case 1, had rheumatoid arthritis starting at the age of 27 years with pain and swelling of fingers. She was given one course of gold, with temporary improvement. Shortly afterwards the shoulders and knees also became painful, but settled after a second course of gold, apart from slight swelling of the hands and intermittent pain in the left arm, without constitutional upset or loss of weight. 3 years later, she began to suffer increasing pain in the left shoulder, which became swollen and finally broke down with sinus formation. The lesion was tuberculous and the joint was arthrodesed in 1944. No other tuberculous focus was found and the patient has remained well ever since apart from slight swelling and deformity of the fingers, tenderness of the right second proximal interphalangeal joint, and some pain in the hands after extra work.

The Rose-Waaler test was positive $1: 32$ in 1957, 16 years after the acute phase.

Case 3, an unmarried woman, aged 43 years, had rheumatoid arthritis starting at the age of 39 years with pain in the feet. Involvement of the hands followed a few months later, with some constitutional upset but no loss of weight.

On admission, the patient complained of pain in most joints, and there was spindling of the fingers, ulnar deviation of the right hand, and a nodule on the right elbow.

Laboratory Findings.-Haemoglobin 46 per cent., white blood cells 12,000 c.mm., polymorphs 96 per cent., lymphocytes 7 per cent.

Blood sedimentation rate $53 \mathrm{~mm} . / 1 \mathrm{hr}$.

The Rose-Waaler test was positive $1: 64$ in 1957 , 2 years after the clinical remission.

Progress.-Shortly after admission she developed a right pleural effusion which proved to be tuberculous, with involvement of the underlying lung. She was transferred to a sanatorium where her progress was stormy at first, but improved after surgery.

She is now working part-time and reports that her joints remained painful until after her operation 2 years ago, but that now all swelling has gone, her hands and feet are normal, and the nodule on her elbow has disappeared. 


\section{Discussion}

About 60 years ago there was much discussion in the European medical literature regarding the possibility of a tuberculous aetiology in certain cases of chronic polyarthritis, which, clinically and radiologically, were indistinguishable from rheumatoid arthritis. A small proportion of these cases were said to develop a typical tuberculous arthritis of one joint at some point in their evolution.

The principal protagonist of this theory was Poncet, who between 1897 and 1909 described the different clinical pictures which he considered might be found in tuberculous rheumatism (Poncet and Leriche, 1909). These included transient arthralgias and acute or subacute rheumatism, which might be primary when they preceded other manifestations of tuberculosis, or secondary when they supervened during the course of visceral tuberculosis. The acute form was apparently indistinguishable from rheumatic fever, while the subacute form resembled rheumatoid arthritis. Poncet thought that the subacute primary form was the commonest, and that in its course the polyarthritis might slowly localize to one joint which later became the site of a typical tuberculous arthritis. He claimed that in such cases injections of tuberculin produced a focal reaction in affected joints and that, on occasion, Koch's bacilli had been cultured from synovial fluid. His views were supported by Thomson (1910) and Raw (1914), but on the whole were not accepted in Great Britain or America.

Interest in the concept faded, but was revived in 1925, mainly through bacteriological work in Paris, where workers claimed to have cultured Koch's bacilli from blood, synovial fluid, and biopsy material from certain patients suffering from apparently typical rheumatoid arthritis. The subject was fully discussed at the III International Congress in 1932, when Besançon, summarizing the findings, concluded that a tuberculous aetiology for the rheumatic process should only be admitted when either the articular and visceral manifestations evolved together, or the rheumatic lesions, after a long or short course, ended by accompanying a florid tuberculous arthritis.

Brav and Hench (1934), in a comprehensive review of the subject, felt that there was as yet no incontrovertible proof of the existence of the syndrome of tuberculous rheumatism. They thought that the presence of Koch's bacilli in a joint, or the development of a typical tuberculous arthritis, might indicate a super-infection of one joint with tubercle, just as easily as that the whole arthritic process was tuberculous.

However, Forestier (1935) considered that there were grounds for believing that tuberculosis was a prominent factor in the aetiology of certain cases of rheumatoid arthritis.

Collins and Cameron (1936), reporting twelve cases of arthritis, in eight of whom visceral tuber- $\stackrel{?}{\rightarrow}$ culosis was proved, though not denying the possible $\bar{?}$ influence of associated visceral tuberculosis on the $\frac{\overline{ }}{\bar{t}}$ production and course of the articular disease, $\frac{\bar{C}}{\vec{D}}$ preferred not to use the term "tuberculous rheu- $\mathbb{Q}$ matism" for two reasons: because every case i pursued a course consistent with non-specific $\vec{D}$ arthritis, and because immobilization treatment, adopted on the suspicion that the condition was $\overrightarrow{\vec{\omega}}$ tuberculous, proved totally unsuitable in each case. $\stackrel{\circ}{\circ}$ They pointed out that the two diseases occurred but rarely in one patient, and that only two patients with true rheumatoid arthritis had been seen among 2,179 tuberculous patients. They quoted Pemberton (1935), who had reported eleven cases of rheu- $\nexists$ matoid arthritis among 4,499 cases of pulmonary 을 tuberculosis, and Brav and Hench's figure of eight cases of tuberculosis among 250 rheumatoid arthritics. They felt that such figures refuted the suggestion that tuberculosis was a frequent or important factor in the aetiology of rheumatoid arthritis.

Copeman (1936), discussing twelve cases of polyarthritis in whom evidence of tuberculosis, including a positive blood culture by Löwenstein's metho\& was found, thought that tuberculosis should considered in the aetiology of any obscure case of rheumatoid arthritis. More recently, Dalgleish 흥 (1952) reported a case of polyarthritis occurring in a young girl, which quickly resolved but was followed $\AA$ by an arthritis of the hip which was clinically and $\overrightarrow{\vec{A}}$ radiologically typical of tuberculosis. No primary $\frac{0}{3}$ focus was discovered and the author felt that the polyarthritis was a sensitization phenomenon to the tubercle bacillus, which later infected the hip joint.

Layani and others (1955), in a careful study of the problem, concluded that the only form of articular $\bar{\sigma}$ disease that could truly be called "tuberculous rheumatism" was a transient acute or subacute $\delta$ polyarthritis occurring during the course of a frank $₹$

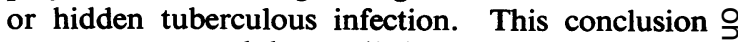
was not accepted by Weil (1955), who was con- $D$ vinced that tuberculosis would cause a chronic polyarthritis.

Short, Bauer, and Reynolds (1957), in their long- Of term study of 293 patients with rheumatoid arthritis, $N$ stated that pulmonary tuberculosis was present in $\underset{\mathrm{C}}{\mathrm{N}}$ five on admission and that four other patients developed it during the study. Two patients in the 0 series developed a tuberculous arthritis; both these $\stackrel{\bar{\Phi}}{\mathbb{D}}$ patients had typical rheumatoid arthritis, one with $\stackrel{?}{+}$ definitive histology in a subcutaneous nodule. One 
later developed a tuberculous arthritis, the other glandular, pulmonary, and articular, tuberculosis. The authors felt that in these two patients coincidental tuberculosis and rheumatoid arthritis were present, but they thought that the possibility of a true tuberculous polyarthritis had to be considered in such cases.

The fact that the Rose-Waaler test (D.A.T.) was positive in all three cases reported in this paper (at a late stage in the disease in Case 1, 16 years after the acute phase in Case 2, and 2 years after clinical remission in Case 3) suggests that, in these cases too, tuberculosis and rheumatoid arthritis were coincidental.

Recent work by Lawrence and Ball (1958) among the relatives of rheumatoid arthritics, showed that 20 per cent. of relatives of sero-positive cases were also sero-positive, though they might be symptomfree. The fact that Case 2 is the sister of Case 1, might thus account for her positive result, which is in low titre; on the other hand, she had a definite polyarthritis which was fairly acute for over a year, and she still has residual swelling and minimal pain in her fingers.

On the whole, it is felt that, though these cases would fit into Poncet's description of subacute primary and secondary tuberculous rheumatism and would fulfil the stricter criteria laid down by Besançon (1932), the finding of a positive Rose-Waaler test (D.A.T.) in all three gives further support to the narrower definition of "tuberculous rheumatism" advanced by Layani and others (1955).

\section{Summary}

The concept of "tuberculous rheumatism" and its evolution is described.

Three cases are reported which fulfil various criteria laid down for tuberculous rheumatism.

The finding of a positive Rose-Waaler test (differential agglutination test) in all three cases, suggests that, in these patients, tuberculosis and rheumatoid arthritis are coincidental.
It is felt that this finding gives support to the narrower definition of tuberculous rheumatism which has been advanced recently.

My thanks are due to Prof. S. J. Hartfall for permission to investigate these cases under his care, to Dr. V. Wright, who kindly did the Rose-Waaler tests (D.A.T.) (using the method of Greenbury), and to Dr. McMillan, who gave me information on the progress of Case 3.

\section{REFERENCES}

Brav, E. A., and Hench, P. S. (1934). J. Bone Jt Surg., 16, 839. Collins, D. H., and Cameron, C. (1936). Brit. J. Surg. 24, 272. Copeman, W. S. C. (1936). Rep. chron. rheum. Dis., No. 2, p. 24. Dalgleish, P. G. (1952). Ann. rheum. Dis., 11, 222

Forestier, J. (1935). J. Lab. clin. Med., 20, 827.

Lawrence, J. S., and Ball, J. (1958). Ann. rheum. Dis., 17, 160.

Layani, F., Durupt, L., and Chaouat, Y. (1955). Rev. Rhum., 22, 548.

Pemberton, R. (1935). "Arthritis and Rheumatoid Conditions", 2nd ed. Baillière, Tindall and Cox, London.

Poncet, A., and Leriche, R. (1909). Med. Press and Circ., n.s. 88, 82 [o.s. 139].

Raw, N. (1914). Lancet, 1, 19.

Short, C. L., Bauer, W., and Reynolds, W. E. (1957). "Rheumatoid Arthritis", p. 52. Harvard Univ. Press, Cambridge, Mass.

Thomson, A. (1910). Edinb. med. J., n.s. 5, 503.

Weil, M. P. (1955). Rev. Rhum., 22, 612.

\section{Rhumatisme tuberculeux \\ RÉSUMÉ}

On décrit la conception du "rhumatisme tuberculeux" et son évolution.

On relate trois cas correspondant à de différents critères proposés pour le rhumatisme tuberculeux.

$\mathrm{La}$ réaction de Rose-Waaler (agglutination différentielle) positive dans les trois cas suggère que chez ces malades la tuberculose et l'arthrite rhumatismale coïncidaient.

On pense que ces résultats supportent une définition du rhumatisme tuberculeux plus étroite que celle proposée récemment.

\section{Reumatismo tuberculoso}

\section{Sumario}

Se describe el concepto de "reumatismo tuberculoso" y su evolución.

Se relatan tres casos que responden a los varios criterios propuestos para el reumatismo tuberculoso.

La reacción de Rose-Waaler (aglutinación diferencial) positiva en los tres casos sugiere que en estos casos la tuberculosis y la artritis reumatoide fueron coincidentes.

Se cree que este resultado sostiene una definición de reumatismo tuberculoso más estrecha que la propuesta recientemente. 